\title{
The Microstructure Evolution of Al-Mg-Sc-Zr Alloy after Deformation by Equal Channel An- gular Pressing
}

Barbora Křivská1, Michaela Šlapáková ${ }^{1}$, Olexandr Grydin², Miroslav Cieslar ${ }^{1}$

${ }^{1}$ Charles University, Faculty of Mathematics and Physics, Ke Karlovu 5, Praha 2, Czech Republic. E-mail: krivska.barbora@seznam.cz, slapakova@karlov.mff.cuni.cz, cieslar@met.mff.cuni.cz

${ }^{2}$ University Paderborn, Faculty of Mechanical Engineering, Lehrstuhl für Werkstoffkunde Microscopy

Pohlweg 47-49, 33098 Paderborn, Germany. E-mail: olexandr.grydin@uni-paderborn.de

Equal-channel angular pressing is a method of severe plastic deformation, which implies high deformation into the material and leads to grain size reduction and strength increase. It was applied on a twin-roll cast Al-Mg-Sc alloy, which contained $\mathrm{Al}_{3}(\mathrm{Sc}, \mathrm{Zr})$ particles formed during annealing at $300{ }^{\circ} \mathrm{C}$ for 8 hours. The evolution of the microstructure and mechanical properties after deformation was studied during isochronal heating $50 \mathrm{~K} / 50 \mathrm{~min}$. Strengthening occurred during annealing at lower temperatures and was followed by prominent microhardness drop, which was connected with formation of new grains and recrystallization. The presence of $\mathrm{Al}_{3}(\mathrm{Sc}, \mathrm{Zr})$ particles in the matrix is accounted for the high temperature stability.

Keywords: Aluminium alloys, Equal-channel angular pressing, $\mathrm{Al}_{3}(\mathrm{Sc}, \mathrm{Zr})$, Thermal stability, Recrystallization

\section{Acknowledgement}

The financial support of Czech Science Foundation project 16-16218S is highly acknowledged.

\section{References}

[1] AHMAD, Z., UL-HAMID, A., ABDUL-ALEEM, B. J. (2001). The corrosion behavior of scandium alloyed Al 5052 in neutral sodium chloride solution, Corrosion Science, 2001, vol. 43, pp. 1227-1243.

[2] HATCH, E. (1984). Aluminium, Properties and Physical Metallurgy. American Society for Metals. Metals Park, Ohio, 1984, p. 47.

[3] HALES, S. J., MCNELLEY T. R., MCQUEEN, H. J. (1991). Recrystallization and superplasticity at $300^{\circ} \mathrm{C}$ in an aluminum-magnesium alloy. Metallurgical Transactions A, 1991, vol. 22A, pp. 1037-1047.

[4] FRIEDMAN, P. A., GHOSH A. K. (1996). Control of superplastic deformation rate during uniaxial tensile tests. Metallurgical and Materials Transaction A, 1996, vol. 27A, pp. 3030-3042.

[5] YUZBEKOVA, D., MOGUCHEVA, A., KAIBYSHEV, R. (2016). Superplasticity of ultrafine-grained Al-MgSc-Zr alloy. Materials Science and Engineering A, 2016, vol. 675, pp. 228-242.

[6] M. LIAO, N. C. BELLINGER, J. P. KOMOROWSKI (2013). Modeling the effects of prior exfoliation corrosion on fatigue life of aircraft wing skins, International Journal of Fatigue, 2013, vol. 25, pp. 1059-1067.

[7] OGUOCHA, I. N. A., ADIGUN, O. J., YANNACOPOULOS, S. (2008). Journal of Materials Science, 2008 , vol. 43, pp. 4208-4214.

[8] PENG, Y., LI, S., DENG, Y., ZHOU, H., XU, G., YIN, G. (2016). Synergetic effects of Sc and Zr microalloying and heat treatment on mechanical properties and exfoliation corrosion behavior of Al-Mg-Mn alloys. Materials Science and Engineering A, 2016, vol. 666, pp. 61-71.

[9] FALLAH, V., LLOYD, D., J., GALLERNEAULT, M. (2017). Processing and characterization of continuous-cast $\mathrm{AlMgSc}(\mathrm{Zr})$ sheets for improved strength. Materials Science and Engineering A, 2017, vol. 698, pp. 88-97.

[10] KARLÍK, M., VRONKA, M., HAUŠILD, P. , HÁJEK, M. (2015). Influence of cold rolling on the precipitation in an Al-Mn-Zr alloy, Materials \& Design, 2015, vol. 85, pp. 361-366.

[11] SUN, K.M., LI, L., CHEN, S.D., XU, G.M., CHEN, G., MISRA, R.D.K., ZHANG, G. (2017). A new approach to control centerline macrosegregation in Al-Mg-Si alloys during twin roll continuous casting, Materials Letters, 2017, vol. 190, pp. 205-208.

[12] BIROL, Y. (2009). Analysis of macro segregation in twin-roll cast aluminium strips via solidification curves, Journal of Alloys and Compounds, 2009, vol. 486, pp. 168-172.

[13] YUN, M., LOKYER, S.,HUNT, J.S. (2000). Twin roll casting of aluminium alloys. Materials Science and Engineering $A$, 2000, vol. 280, pp. 116-123. 
[14] ŠLAPÁKOVÁ, M., KŘIVSKÁ, B., GRYDIN, O., CIESLAR, M. (2017). The Influence of Casting Methods on Microstructure of Al-Mg-Sc-Zr Alloy. Manufacturing Technology, 2017, vol. 17, submitted.

[15] VLACH, M., ČÍŽEK, J., SMOLA, B., MELIKHOVA, O., VLČEK, M., KODETOVÁ, V., KUDRNOVÁ, H., HRUŠKA, P. (2017). Heat treatment and age hardening of Al-Si-Mg-Mn commercial alloy with addition of Sc and $\mathrm{Zr}$, Materials Characterization, 2017, vol. 129, pp.1-8.

[16] VLACH, M., STUlikOVA, I., SMOLA, B., PIESOVA, J., CISAROVA, J., DANIS, S., PLASEK, J., GEMMA, R., TANPRAYOON, D., NEUBERT, V. (2012). Effect of cold rolling on precipitation processes in Al-Mn-ScZr alloy, Materials Science and Engineering: A, 2012, vol. 548, pp. 27-32.

[17] JIA, Z., FORBOD, B., SOLBERG, J. (2007). Effect of homogenization and alloying elements on recrystallization resistance of Al-Zr-Mn alloys. Materials Science and Engineering A, 2007, vol. 444, pp. 284-290.

[18] KARLÍK, M., MÁNIK, T., SLÁMOVÁ, M., LAUCHMANN, H. (2012). Effect of Si and Fe on the Recrystallization Response of Al-Mn Alloys with Zr addition. Acta Physica Polonica A, 2012, vol. 122, pp. 469-474.

[19] WANG, Z., LI H., MIAO, F., FANG, B., SONG, R., ZHENG, Z. (2014). Improving the strength and ductility of $\mathrm{Al}-\mathrm{Mg}-\mathrm{Si}-\mathrm{Cu}$ alloys by a novel thermo-mechanical treatment, Materials Science and Engineering: A, 2014 , vol. 607, pp 313-317.

[20] CIESLAR, M., BAJER, J., ŠLAPÁKOVÁ, M., KŘIVSKÁ, B., ZIMINA, M., GRYDIN, O. (2017). Microstructure of Twin-Roll Cast Al-Mg-Sc-Zr Alloy. Materials Today: Proceedings, 2017, in press.

[21] VALIEV, R. Z., LANGDON, T. G. (2006). Principles of equal-channel angular pressing as a processing tool for grain refinement. Progress in Materials Science, 2006, vol. 51, pp. 881-981.

[22] KRAJŇÁK, T., MINÁRIK, P., STRÁSKÁ, J., GUBICZA, J., MÁTHIS, K., JANEČEK, M. (2017). Influence of equal channel angular pressing temperature on texture, microstructure and mechanical properties of extruded AX41 magnesium. Journal of Alloys and Compounds, 2017, vol. 705, pp. 273-282.

[23] ŠLAPÁKOVÁ, M., KŘIVSKÁ, B., BAJER, J., GRYDIN, O., CIESLAR, M. (2017). Al-Mg-Sc Alloys processed by Equal-Channel Angular Pressing. In METAL 2017: $26^{\text {rd }}$ International Conference on Metallurgy and Materials. Ostrava: TANGER, 2017.

[24] CIESLAR, M., BAJER, J., ZIMINA, M., ŠLAPÁKOVÁ, M., GRYDIN, O. (2017). Properties and microstructure of twin-roll cast Al-Mg alloy containing Sc and Zr. IOP Conf. Series: Materials Science and Engineering, 2017, vol. 179, pp. 012012.

[25] CIESLAR, M., BAJER, J., ZIMINA, M., GRYDIN, O. (2016). Microstructure of Twin-roll Cast Al-Mg-Sc-Zr Alloy. Manufacturing Technology, 2016, vol. 16, no. 6, pp. 1255-1259.

[26] POKOVÁ, M., CIESLAR, M. (2014). Study of Twin-roll Cast Aluminium Alloys Subjected to Severe Plastic Deformation by Equal Channel Angular Pressing. Materials Science and Engineering, IOP Conference Series, 2014, vol. 63, p. 012086. 